\title{
THE EFFICIENCY OF MANUFACTURING SECTOR: EMPIRICAL EVIDENCE FROM ACEH PROVINCE INDONESIA
}

\author{
Muhammad Nasir")1, Eva Arafah"), and Hizir Sofyan*) \\ *) Faculty of Economics and Business, Syiah Kuala University \\ Jln. Teuku Nyak Arief, Darussalam, Banda Aceh, Aceh, 23111 \\ ${ }^{* *}$ Faculty of Matematics and Natural Sciences, Syiah Kuala University \\ Jln. Teuku Nyak Arief, Darussalam, Banda Aceh, Aceh, 23111
}

\begin{abstract}
This paper was aimed to analyze the efficiency of Manufacturing Sector in Province of Aceh - Indonesia. The analysis was conducted using the secondary data on manufacturing sector of Province of Aceh together with the Data Envelopment Analysis (DEA analysis). Based on the research, it was found that the manufacturers that had highest output included those producing Fertilizer, Chemical, and Rubber whereas the manufacturers that had the lowest output included Foods and Tobaccos. This condition was caused by the lower interest of the producers involving in foods and tobaccos products. By using DEA analysis, the efficiency value of each product is varied. Using constant return to scale (CRS) assumption, there are four manufactures that are not efficient, including Foods and Tobaccos, Textile, Animal skin products and shoes, and Fertilizer, Chemical, and Rubber products.
\end{abstract}

Keywords: efficiency, manufacturing sector, data envelopment analysis

\begin{abstract}
Abstrak: Paper ini bertujuan menganalisa efisiensi sektor industri di Propinsi Aceh- Indonesia. Analisa dilakukan dengan menggunakan data sekunder terhadap sektor industri di Propinsi Aceh secara bersamaan dengan Data Envelopment Analysis (DEA). Berdasarkan hasil penelitian, ditemukan bahwa industri yang memiliki output tertinggi adalah pupuk, kimia dan kulit. Sementara industri yang memiliki output terendah adalah makanan dan tembakau. Kondisi ini disebabkan oleh perhatian produsen yang rendah yang terlibat dalam produk makanan dan tembakau. Dengan menggunakan analisa DEA, nilai efisiensi dari setiap produk adalah beragam. Dengan menggunakan asumsi constant return to scaale (CRS), ada empat industri yang tidak efisien yaitu makanan dan tembakau, tekstil, produk kulit dan sepatu, pupuk, produk kimia dan karet.
\end{abstract}

Kata kunci: efisiensi, sektor industri, data envelopment analysis

\section{INTRODUCTION}

Economic developments that have been conducted by developing countries are aimed to strengthen the national economy, increase economic growth, provide employment, increase per capita income and reduce regional income disparities. An effort to improve economic development is by the development of manufacturing sector where this sector becomes a long run effort in order to improve economic structure and make balance between manufacturing and agricultural sectors (Adugna, 2014). This is reasonable because manufacturing sector has become the important sector in Indonesian economy after transformation process. The reason has been also supported by the

${ }^{1}$ Corresponding author:

Email: nasirmsi@unsyiah.ac.id higher contribution of that sector in Indonesian Gross Domestic Product (GDP) nowadays.

Indonesia as one of the developing countries is also preparing the manufacturing sector in order to be the engine of the economic growth and other sectors as well. Manufacturing sector is expected to be the leading sector in the developed economy. Manufacturing sector is also considered as the good sector that can create employment opportunity. Furthermore, the bigger population of Indonesia has become the potential for the demand of the products that can create economies of scale in the production process.

The availability of human resources can also create the positive change in the economy. Better quality of human resources will drive economic growth. This kind of human resources will have a good impact on 
productivity and efficiency. Processing manufacturing in Aceh Province has not given an optimal contribution to Aceh's Gross Domestic Regional Product (GDRP) in 2010 where the contribution of that sector was only $10.56 \%$. Nevertheless, this sector has to be pushed to be developed because of its significant value added and significant rule of labor absorption.

The processing manufacturing sector has been in the fourth position in terms of GDRP contribution in Aceh Province with the contribution as much as $10.36 \%$. Meanwhile, trade, hotel and restaurant sector gave a contribution to Aceh's GDRP as much as $19.98 \%$ in year 2011 .

The reason for investigating the efficiency of manufacturing sector in Aceh Province was because this sector will be the potential sector of postera of oil and gas. Previously, Aceh Province relied on oil and gas production as main sources of domestic income. For the future, manufacturing sector is hoped to have a good economic prospect in contributing to Aceh's GDRP.

In the production process, efficiency has become the problem that is difficult to solve because in Indonesia there are a lot of problems that must be solved in order to increase efficiency. Lack of the capital in development process has been the specific problem that has to be solved as well; this is because lack of capital can reduce efficiency. In order to increase the output, more capital is needed. Besides that, the government has to expand the scope of development of education system and infrastructures.

The other effort that has to be done in order to increase output is by developing the classifications of entrepreneurs. Those classifications are very important in determining the successfulness of economic growth because the more capital owned by the entrepreneurs, the faster efficiency can be achieved. It is well known that better developed firms and industries will contribute to economic growth and employment opportunity.

Efficiency has been an important issue nowadays and in the future. This is caused by: (1) the limited amount of resources, (ii) the increase in competitiveness, (iii) the increase in consumer satisfaction standard, and (iv) the increase in life quality. Thus, efficiency analysis is most important and can determine the kind of treatment in the effort to increase efficiency. Based on those issues, the researchers will analyze the efficiency of processing manufactures in Aceh Province using Data Envelopment Analysis (DEA) Method.

According to Chenery in Tambunan (2001), even the process of industrialization varies from one country to another; industrialization is the logic step in the process of structural change in the economy. This step is implied historically by the increase in the contribution of manufacturing sector in consumers' demand, GDP, export and employment opportunity. Hypothetically, there is positive correlation in structural change with industrialization.

Efficiency is an important aspect of the production and in manufacturing sector. Efficiency can be defined as the ratio between output and input used. According to Syafroedin in Akbar (2010), one firm can be said efficient if: (1) it can use less inputs compared to the inputs used by other firms to produce the same output, (2) it can use the same amount of inputs, but produce more outputs. Nicholson in Kurniasari (2011) stated that one activity has been done efficiently if the undertaken activity has achieved the target with the sacrifice of less inputs whereas, according to Vincent (1999), efficiency is the measurement of how good the economic resource is in the process of producing output.

One method in measuring efficiency is by using Data Envelopment Analysis (DEA). It is a nonparametric analysis using Linear Programming to calculate the ratio between output and input. The method was firstly introduced by Charnes, Cooper, and Rhodes (CCR) in 1978. This method does not need the production function and the result of calculation is relative efficiency value (Prasetyo, 2008: Wu et al. 2014: Yannick et al. 2016: Chen and Guozhu, 2017: Mardani et al. 2017: Olesen at al. 2017). DEA method has been used in many researches on manufacturing sector and company performance. For instance, Tanase and Tidor (2012) applied DEA and Malmquist productivity index (MPI) in evaluating the efficiency and changing productivity in the machinery industry in Romania during 2001-2010. Like Indonesia, machinery industry is an important economic key in Romania. Tanase and Tidor (2012) examined the efficiency and productivity of enterprises with more than 250 employees in the machinery industry. They found that the tendency of growth in total factor productivity (TFP) was affected by the efficiency process, not by the technological change. 
The application of DEA method can be also found in Mandal and Madheswaran (2009). They tried to investigate the environmental efficiency in Indian cement industry within a joint production framework of both desirable and undesirable outputs using DEA and Directional Distance Function. Based on their research, it was found that there is enough potential for the industry to improve its environmental efficiency.

Banaeian and Zangeneh (2011) also used DEA in the study of determination of energy use, qualitative analysis of energy flow and energy efficiency effects on corn production in Iran for the seven-year period. The study found that the average total energy input increased from $40.98 \mathrm{Gj}$ ha in 2001 to $63.64 \mathrm{Gj}$ ha in 2007. There was the impermanent trend in the growth of energy efficiency in corn production in Iran.

Related to energy efficiency in manufacturing sector, Zheng and Lin (2017) studied the impact of industrial policies in improving energy efficiency. They found that the ownership structure did not affect energy efficiency and the energy efficiency in paper industry in China can be improved by the scale of the economy.

Wu et al. (2016) studied efficiency of wind farms in China by using the two stage data envelopment analysis i.e. by analyzing the production efficiency of 42 largescale wind farms. In the first stage, the efficiency scores of wind farms were determined by DEA, and in the second stage, the Tobit regression was used in exploring the relationship between efficiency scores and environmental variables. The research showed that all wind farms operated at the acceptable level of production.

There was also another research of efficiency analysis in China for the agricultural sector. This study was conducted by Liu et al. (2015). The data used were the data on prefecture-level cities in North-East China from 2000 to 2012. The finding showed that the mean of the pure efficiency in a DEA model in agriculture was 0.79 , and the average productivity of Malmquist index (MALM) growth was $8.0 \%$.

Furthermore, Cesaroni (2017) used data envelopment analysis (DEA) with a variable return to scale (VRS) technology with the concept of cost minimizing industry structure which features reallocation of outputs and variable number of firms. According to him, in the application, this approach uses an algorithm to solve the related nonlinear programming.

Based on the literature review and other research findings, it can be seen that there is lack of researches on efficiency of sub-sector of manufacture as the subsector of GDRP. Many researches have focused on a special kind of manufacturing sector. In this research, the researchers focused on the sub-sectors of the manufacturing sector in Aceh Province.

\section{METHODS}

The scope of this research was limited to Province of Aceh, Indonesia by using secondary data that had been collected from many government institutions in the province and other related institutions. The data used were for manufacturing sector especially processing manufacture in the province in 2010. The data used were for one year for five sub-sectors of manufacturing based on the criteria of the Indonesia Statistics (BPS).

In analyzing the efficiency of manufacturing sector in Aceh, the model of analysis used was the Data Envelopment Analysis (DEA). According to Cooper et al. in Akbar (2010), DEA can be used "as mathematical programming which can handle large numbers of variables and constraints..." Thus, DEA method can avoid the limitation in regression analysis by avoiding bias problem and classical assumption violations.

According to Färe et al. and Rao et al. (2004), and given the availability of panel data, it is possible to calculate the distance measures for the Malmquist TFP index by using DEA-like linear programs. Fare et al. in Rao et al. (2004) also assumed the CRS technology in the analysis. Then the required four linear programming (LPs) problems are as follow:

$$
\begin{array}{ll}
{[\mathrm{d} 0 \mathrm{t}(\mathrm{yt},} & \mathrm{xt})]-1=\max \Phi, \lambda \Phi, \\
\text { st } \quad & -\Phi y i t+\mathrm{Yt} \lambda \geq 0, \\
& \text { xit }-\mathrm{Xt} \lambda \geq 0, \\
& \lambda \geq 0, \\
{[\mathrm{~d} 0 \mathrm{~s}(\mathrm{ys},} & \mathrm{xs})]-1=\max \Phi, \lambda \Phi, \\
\text { st } \quad & -\Phi y i s+\mathrm{Ys} \lambda \geq 0, \\
& \text { xis }-\mathrm{Xs} \lambda \geq 0, \\
& \lambda \geq 0,
\end{array}
$$




$$
\begin{aligned}
& {[\mathrm{d} 0 \mathrm{t}(\mathrm{ys}, \mathrm{xs})]-1=\max \Phi, \lambda \Phi,} \\
& \text { st } \quad-\Phi y \text { is }+\mathrm{Yt} \lambda \geq 0 \text {, } \\
& \text { xis }-X \mathrm{t} \lambda \geq 0 \text {, } \\
& \lambda \geq 0 \text {, } \\
& {[\mathrm{d} 0 \mathrm{~s}(\mathrm{yt}, \mathrm{xt})]-1=\max \Phi, \lambda \Phi,} \\
& \text { st } \quad-\Phi y i t+Y s \lambda \geq 0, \\
& \text { xit }-\mathrm{Xs} \lambda \geq 0 \text {, } \\
& \lambda \geq 0 \text {, }
\end{aligned}
$$

Where: yit is a Mx1 vector of output quantities for the $\mathrm{i}$-th sector in the period $\mathrm{t}$; $\mathrm{xit}$ is a $\mathrm{Kx} 1$ vector of input quantities for the $\mathrm{i}$-th sector in the period $\mathrm{t}$; $\mathrm{Yt}$ is a NxM matrix of output quantities for all $\mathrm{N}$ sectors in the period $\mathrm{t}$; $\mathrm{Xt}$ is a NxK matrix of input quantities for all $\mathrm{N}$ sectors in the period $t ; \lambda$ is a Nx1 vector of weights; $\Phi$ is a scalar.

According to Coelli et al. (1998), in the linear programming (LP) in 1 and 2 where the production points are compared to technologies from the different periods, the $\Phi$ parameter has to be greater than or equal to 1 . This is similar to the calculation of Farrell outputoriented technical efficiencies. So far, the data point will be above the feasible production set. However, in this calculation if the technical progress has occurred, then the value of $\Phi$ parameter less than one is possible. This condition will occur in the equation 2 in which a production point from period $t$ is compared to the technology in previous period. It is also possible that the technical regress occurs but it is less likely to occur such as in LP problem in equation 1.

In an input-oriented case of DEA model where the inputs are minimized and outputs are maintained at their current levels, $\Phi$ is equal to 1 . Then it will be the feasible solution of linear programming problems. The optimal value of the problems will be $\Phi^{*} \leq 1$. If $\Phi^{*}=1$, the current input levels may not be reduced proportionally which means that the respective decision making units (DMU) is on frontier. In contrast, if $\Phi^{*}$ $<1$, the respective DMU is dominated by the frontier. Thus, $\Phi^{*}$ represents the input-oriented efficiency score of DMU (Zhu, 2003).

Zhu (2003) in his book stated that DEA Excel Solver would be used in calculating the Malmquist index and introduced the term: $\mathrm{h}$ decision making unit (DMU) to represent business operations or production processes. As the production unit, each DMU such as firms has a set of inputs and also outputs that represent multiple performance measures. Let us consider a set of $n$ observations on DMUs. Then, each observation, DMUj $(j=1, \ldots, n)$ uses $m$ inputs xij $(i=1,2, \ldots, m)$ to produce $\mathrm{s}$ outputs yrj $(\mathrm{r}=1,2, \ldots, \mathrm{s})$. In reference to Zhu (2003), the efficient frontier is determined by the n observations. In developing a piecewise linear approximation to the efficient frontier, it has to be ensured that the two properties; convexity and inefficiency are fulfilled.

\section{Property 1: Convexity.}

$\sum_{j=1}^{n} \mathrm{I}_{j} x_{j}(i=1,2, \ldots, m)$ and $\sum_{j=1}^{n} \mathrm{I}_{j} y_{\dot{j}}(r=1,2, \ldots, s)$ are possible inputs and outputs achievable by the DMUj, where $\lambda j(j=1, \ldots, n)$ are nonnegative scalars such that $\sum_{j=1}^{n} \mathrm{I}_{j}=1$.

Property 2: Inefficiency. The same $\mathrm{y}_{\mathrm{rj}}$ can be obtained by using $\hat{x}_{i j}$ where $\hat{x}_{i j} \geq x_{j}$ which means that the same outputs can be produced by using more inputs; and the same can be used to obtain $\hat{y}$, where $\hat{y}_{\dot{j}} \leq y_{\dot{j}}$ that means the same inputs can be used to produce less outputs.

In this research, variable return to scale (VRS) assumption was used so that all units that had been calculated give the change in all output levels. Besides, the technology term also can be accommodated by this assumption that give the possibility for economies of scale. In terms of Constant return to scale (CRS) assumption, the increase in one input will be followed by one output. For the basis of firm efficiency calculation, this study used the Data Envelopment Analysis (DEA) where this analysis was based on the linear programming method in calculating the relative efficiency to a group of economic activities that are comparable. This method is also a procedure that had been designed to measure relative efficiency using more inputs and outputs, where the combination between inputs and outputs are invisible to be conducted.

In economics point of view, one rational firm will try to maximize the profit that it owns. In line with that condition, rational firm will always increase production capacity until reaching the equilibrium condition in profit maximization, where marginal revenue is equal to marginal cost. Thus the firms have to be sensitive for the issues related to "return to scale". One firm will have one condition: increasing return to scale (IRS), 
constant return to scale (CRS) and decreasing return to scale (DRS). If the firm is in IRS condition, then one percent increase in input will increase $1 \%$ output; thus, the firm will always increase production capacity. The same condition will be also applied for CRS condition where $1 \%$ increase in input will give additional increase of exactly 1\% (Siswandi and Arafat in Akbar, 2010).

The DEA approach used in this research was input oriented DEA. It is assumed that either input oriented or output oriented will give the same efficiency scores. The difference is in the objective function either to maximize or to minimize. According to Rajasekar and Deo (2014), there is no difference between the efficiency on its orientation, i.e. either input oriented or output oriented. Input-oriented DEA minimizes the inputs for desired level of output to be achieved, while output oriented DEA model maximize the inputs with input kept at the constant level.

The efficiency of manufacturing sectors is measured using DEA analysis that shows the performance of manufacturing sector technically. The efficiency levels are obtained by comparing the output with the inputs. The efficiency values are relative, and that can be seen by the ratio of outputs and inputs with the value between 0 and 1 . One firm is said to be efficient when its efficiency is close to one and vice versa. The inputs data used are capital, labor, and raw material, whereas the outputs include goods and services produced.

\section{RESULTS}

The analysis of manufacturing sector in processing manufacture in Aceh Province was undertaken by using the input minimization approach. By DEA analysis, the interpretation of manufacture evaluation in tobaccos, textile, skin, fertilizer, chemistry, iron and other industries would be easy, and this is because the values produced by DEA. The calculation of technical efficiency in the manufacturing sector with DEA had been conducted by using three inputs i.e. capital, raw material and labor) and one output i.e. goods and services. The calculation results then were arranged by manufacturing sector classification in order to be compared with technical efficiency between the industries.
Based on Table 1, it can be seen that the manufacture that has the highest outputs include Fertilizer, chemical, and Rubber with the output of IDR488,030,013,000 whereas the manufacture that has the lowest outputs include Foods and Tobaccos with the output as much as IDR86,438,490,150. This condition was caused by the lower interest of the producers involved in food and tobacco products.

By using the DEA method, the efficiency values of each product are varied. Using the constant return to scale (CRS) assumption, there are four manufactures that are not efficient including Foods and tobaccos, textile, animal skin products and shoes, and Fertilizer, chemical, and rubber products. The achievement of $100 \%$ efficiency was obtained only by the Steel industry.

Generally, the productivity of those four industries measured by the ratio of outputs to inputs is not efficient, except for the steel industry. This ratio shows the average contribution of labor on the output. Details on efficiency measurements are presented by Table 2 .

From the Table 2, it shows that: The calculation of efficiency using the assumption of Constant Return to Scale (CRS) shows that one sector in Processing manufacturing had operated efficiently. The calculation of efficiency using the assumption of Variable Return To Scale (VRS) shows that 3 sectors had operated efficiently including Foods and Tobaccos, Fertilizer, chemical and rubber, and steel. The comparison between CRS and VRS assumptions above show that there is low efficiency in CRS assumption; thus, VRS assumption was chosen.

The assumption chosen in this research was Variable Return to Scale (VRS) that assumed that technology affected efficiency value, and the assumption was also in line with input oriented production process. The processing manufacturing sector is said to be efficient when it has efficiency value of one whereas, the inefficient industrial sector is shown by the efficiency value of below one.

The calculation of efficiency value with the assumption of Variable Return to Scale shows two industries that had not operated efficiently. The values indicate that the other industries did not use the resources optimally in producing the output. 
Table 1. The amount of capital, labor, raw materials and outputs

\begin{tabular}{lrrrr}
\hline \multicolumn{1}{c}{ Manufacture Sector } & \multicolumn{1}{c}{ Capital (IDR) } & Labor (people) & Raw material (IDR) & Output (IDR) \\
\hline Foods and Tobaccos & $48,163,737,000$ & 6,407 & $43,066,511,000$ & $86,438,490,150$ \\
Textile, Animal Skin Product and Shoes & $178,780,362,000$ & 35,869 & $321,464,410,000$ & $468,392,133,000$ \\
Fertilizer, chemical, and Rubber & $607,118,318,000$ & 43,012 & $269,337,102,000$ & $488,030,013,000$ \\
Steel & $65,738,711,000$ & 9,702 & $152,064,693,000$ & $325,132,674,000$ \\
Others & $48,729,346,000$ & 16,581 & $93,228,389,000$ & $184,661,565,000$ \\
\hline
\end{tabular}

Source: Industrial Department of Aceh Province, 2010

Table 2. The efficiency measurements of processing manufacturing sector 2010 with CRS and VRS input minimization

\begin{tabular}{lcc}
\hline \multicolumn{1}{c}{ Manufacture } & $\begin{array}{c}\text { Input-or CRS } \\
\text { efficiency }\end{array}$ & $\begin{array}{c}\text { Input-or VRS } \\
\text { efficiency }\end{array}$ \\
\hline $\begin{array}{l}\text { Foods and Tobaccos } \\
\text { Textile, Animal Skin }\end{array}$ & 0.397 & 1.000 \\
$\begin{array}{l}\text { Products, and shoes } \\
\text { Fertilizer, chemical, and }\end{array}$ & 0.526 & 0.793 \\
rubber & 0.314 & 1.000 \\
Steel & 1.000 & 1.000 \\
Other Goods & 0.767 & 0,452 \\
\hline
\end{tabular}

The use of Data Envelopment Analysis (DEA) method can give the strategic advice for the businessmen in increasing the efficiency in Economic Activity Unit especially processing industry by introducing optimal input use. Thus, the industrial management does not only know inefficient sector but it also knows by how much the input and output have to be adjusted in order to have high efficiency.

Based on Table 2, the efficiency of sub sector of Foods and Tobaccos, Fertilizer, chemical, and rubber and steel show high efficiency. In term of business development, those sub-sectors are profitable to be developed in Aceh. With high efficiency, there is the opportunity to have higher profit. There is also the possibility for higher return on investment. Indeed, the role of government is needed to develop industry as strategic sector as suggested by Syahran et al. (2016).

Foods and Tobaccos industry has an efficiency score of $1(100 \%)$ with the capital target as much IDR4,816,737,000, labor target as much as 6.407 people, raw material target as much as IDR43,066,511,000, services and other targets as much as IDR $86,438,490,150$ (Table 3). This implies that the use of inputs was optimal and based on efficiency target. This condition should be maintained in the production process so that the businessmen can get higher profits.

The increase in efficiency in textile, animal skin products, and shoes industry can be carried out by using capital as much as IDR178,780,362,000, labor as much as 35,869 people, raw material as much as IDR254,644,000,000 (Table 4). On the other hand, by using inputs that are more efficient, the output target of services and other sectors can be achieved by the amount of IDR468.392,133,000.

Fertilizer, chemical and rubber industry has an efficiency score of $1(100 \%)$ with the target of capital as much as IDR607,118,318,000, target of labor as much as 43,012 people, target of raw material as much as IDR269,337,102.000, target of services and others as much as IDR488,030,013,000 (Table 5). This is the sign of the optimal input use in the production process; thus, it needs to be maintained so that the businessmen can get higher profits.

Table 6 shows the efficiency of Steel Industry that has an efficiency score of $1(100 \%)$ with the target of capital as much as IDR65,738,711,000, target of labor as much as 9,702 people, target of raw material as much as IDR152,064,693.000, target of services and others as much as IDR325,132,674,000. This implies that the inputs use were optimal in the production process.

Finally, Table 7 shows the efficiency improvement in other industrial products with the use of capital as much as IDR48,729,346,000 with the target of labor as much 7,230 people, and the target of raw material as much as IDR87,695,000.000 in the effort to have the product of services and others as much as IDR184,661,565,000. The detail can be shown by Table 7 . 
Table 3. Input and output target in foods and tobaccos Industry Year 2010 (DEA calculation)

\begin{tabular}{|c|c|c|c|c|c|c|}
\hline Industry & & Variable & Actual (IDR) & Target (IDR) & $\begin{array}{l}\text { To Achieved } \\
\text { (percent) }\end{array}$ & Scale efficiency \\
\hline \multirow{4}{*}{$\begin{array}{l}\text { Foods and } \\
\text { Tobaccos }\end{array}$} & \multirow[t]{3}{*}{ Input } & Capital & $48,163,737,000$ & $48,163,737,000$ & 100 & \multirow[t]{4}{*}{ IRS } \\
\hline & & Labor & 6,407 & 6,407 & 100 & \\
\hline & & Raw material & $43,066,511,000$ & $43,066,511,000$ & 100 & \\
\hline & Output & $\begin{array}{l}\text { Services and } \\
\text { others }\end{array}$ & $86,438,490,150$ & $86,438,490,150$ & 100 & \\
\hline
\end{tabular}

Table 4. Input and output target in textile, animal skin products, and shoes year 2010 (DEA calculation)

\begin{tabular}{|c|c|c|c|c|c|c|}
\hline Industry & & Variable & Actual (IDR) & Target (IDR) & $\begin{array}{l}\text { To Achieved } \\
\text { (percent) }\end{array}$ & Scale efficiency \\
\hline \multirow{4}{*}{$\begin{array}{l}\text { Textile, } \\
\text { Animal Skin } \\
\text { Products, and } \\
\text { shoes }\end{array}$} & \multirow[t]{3}{*}{ Input } & Capital & $178,780,362,000$ & $178,780,362,000$ & 100 & \multirow[t]{4}{*}{ DRS } \\
\hline & & Labor & 35,869 & 35,869 & 100 & \\
\hline & & Raw material & $321,464,410,000$ & $254,644,000,000$ & 79 & \\
\hline & Output & $\begin{array}{l}\text { Services and } \\
\text { others }\end{array}$ & $468,392,133,000$ & $468,392,133,000$ & 100 & \\
\hline
\end{tabular}

Table 5. Input and output target in fertilizer, chemistry and rubber industry year 2010 (DEA calculation)

\begin{tabular}{|c|c|c|c|c|c|c|}
\hline Industry & & Variable & Actual (IDR) & Target (IDR) & $\begin{array}{c}\text { To Achieved } \\
\text { (percent) }\end{array}$ & Scale efficiency \\
\hline \multirow{4}{*}{$\begin{array}{l}\text { Fertilizer, } \\
\text { Chemical, and } \\
\text { Rubber }\end{array}$} & \multirow[t]{3}{*}{ Input } & Capital & $607,118,318,000$ & $607,118,318,000$ & 100 & \multirow[t]{4}{*}{ DRS } \\
\hline & & Labor & 43,012 & 43,012 & 100 & \\
\hline & & Raw material & $269,337,102,000$ & $269,337,102,000$ & 100 & \\
\hline & Output & $\begin{array}{l}\text { Services and } \\
\text { others }\end{array}$ & $48,803,013,000$ & $488,030,013,000$ & 100 & \\
\hline
\end{tabular}

Table 6. Input and output targets in steel industry year 2010 (DEA calculation)

\begin{tabular}{|c|c|c|c|c|c|c|}
\hline Industry & & Variable & Actual (IDR) & Target (IDR) & $\begin{array}{l}\text { To Achieved } \\
\text { (percent) }\end{array}$ & Scale efficiency \\
\hline \multirow[t]{4}{*}{ Steel } & Input & Capital & $65,738,711,000$ & $65,738,711,000$ & 100 & CRS \\
\hline & & Labor & 9,702 & 9,702 & 100 & \\
\hline & & Raw material & $152,064,693,000$ & $152,064,693,000$ & 100 & \\
\hline & Output & $\begin{array}{l}\text { Services and } \\
\text { others }\end{array}$ & $325,132,674,000$ & $325,132,674,000$ & 100 & \\
\hline
\end{tabular}

Table 7. Input and output target at other industrial product year 2010 (DEA calculation)

\begin{tabular}{|c|c|c|c|c|c|c|}
\hline Industry & & Variable & Actual (IDR) & Target (IDR) & $\begin{array}{l}\text { To Achieved } \\
\text { (percent) }\end{array}$ & Scale efficiency \\
\hline \multirow{4}{*}{$\begin{array}{l}\text { Other } \\
\text { Industrial } \\
\text { Products }\end{array}$} & \multirow[t]{3}{*}{ Input } & Capital & $48,729,346,000$ & $48,729,346,000$ & 100 & \multirow[t]{4}{*}{ IRS } \\
\hline & & Labor & 16,581 & 7,230 & 45 & \\
\hline & & Raw material & $93,228,389,000$ & $87,695,000,000$ & 94 & \\
\hline & Output & $\begin{array}{l}\text { Services and } \\
\text { others }\end{array}$ & $184,661,565,000$ & $184,661,565,000$ & 100 & \\
\hline
\end{tabular}




\section{Managerial Implications}

The managerial implication of the research finding shows that the achievement of $100 \%$ efficiency is only on Steel industry. This indicates that the steel producers have efficiently utilized the labor, capital, and raw materials. By this condition, in order to maintai the optimal profit, the producers should not add any additional inputs in the production process in the short run. However, in the long run if they want to increase substantial outputs, they can do the expansion path of their production isoquants by maintaning the same ratio of inputs and outputs. On the other hand, the efficiency level in steel industry induces higher profit for the investors. Thus this sector has a good business prospect.

\section{CONCLUSIONS AND RECOMMENDATIONS}

\section{Conclusions}

DEA method can be used to measure the relative efficiency of one economic activity unit that has relatively the same input-output. The comparison of the efficiency of all manufacturing sectors for processing manufacture with the assumption of constant return to scale and variable return to scale results in relatively the same efficiency scores. This is inline with the previous findings on DEA method where either input oriented DEA or ouput oriented DEA gave the same effciciency results. Thus, the assumption had been changed to variable return to scale. The efficiency scores of all processing manufacture shows that there are three efficient sectors including foods, fertilizer, and iron whereas the other two manufacturing sectors (textile and others) are inefficient, and this was caused by the higher input costs.

\section{Recommendations}

In reference to the results of DEA analysis on manufacturing sector, it can be recommended that the government can give more attentions in supporting foods, fertilizer, and iron sub-sector of industry to be the competitive sub-sector, whereas, in the meantime, the government should have a favorable policy toward inefficient sub-sectors in manufacturing sector by increasing the capacity in terms of capital and labor. For the private sector, the investors can improve and invest in sub-sectors of foods, fertilizer, and iron because these three sub-sectors have advantages and may result in profitability of the business, and there will also be the higher return on investment for the investors.

\section{REFERENCES}

Adugna T. 2014. Impacts of manufacturing sector on economic growth in Ethiopia: akaldorian approach. Journal of Business Economics and Management Sciences 1(1): 1-8.

Akbar RA. 2010. Analysis of efficiency in Baitul Mal Wa Tamwil using DEA [tesis]. Semarang: University of Dipenogoro.

Banaeian N, Morteza Z. 2011. Study on energy efficiency in corn production of Iran. Energy 36(8): 5394-5402. https://doi.org/10.1016/j. energy.2011.06.052.

Cesaroni G. 2017. Industry cost efficiency in data envelopment analysis. Socio-Economic Planning Sciences 61:37-43. https://doi.org/10.1016/j. seps.2017.01.001.

Chen L, Guozhu J. 2017. Environmental efficiency analysis of China's regional industry: a data envelopment analysis (DEA) based approach. Journal of Cleaner Production 141(2017): 846-853. https://doi.org/10.1016/j. jclepro.2016.01.045.

Coelli TJ, Rao DSP, Battese GE. 1998. An Introduction to Efficiency and Productivity Analysis. Boston: Kluwer Academic Publisher. https://doi. org/10.1007/978-1-4615-5493-6.

Liu S, Pingyu Z, Xiuli H, Jing L. 2015. Efficiency change in North-East China agricultural sector: a DEA approach. Agricultural Economics (Zemědělská Ekonomika) 61(11): 522-532. https://doi. org/10.17221/233/2014-AGRICECON.

Mandal SK, Madheswaran S. 2009. Environmental efficiency of the Indian cement industry: An interstate analysis. Energy Policy 38(2):1108-1118.https://doi.org/10.1016/j. enpol.2009.10.063.

Mardani A, Edmundas KZ, Dalia S, Ahmad J, Masoumeh K. 2017. A comprehensive review of data envelopment analysis (DEA) approach in energy efficiency. Renewable and Sustainable Energy Reviews 70(2017): 1298-1322. https:// doi.org/10.1016/j.rser.2016.12.030.

Olesen OB, Niels CP, Victor VP. 2017. Efficiency measures and computational approach for data envelopment analysis models with ratio inputs and ouputs. European Journal of Operational 
Research 261(2017): 640-655. https://doi. org/10.1016/j.ejor.2017.02.021.

Prasetyo D. 2010. Analysis of technical and allocative efficiency in Tawangmangu Tourism Region in Kabupaten Karanganyar using DEA method [thesis].Solo: University of Sebelas Maret.

Rajasekar T, Deo M. 2014. Is there any efficiency difference between input and output oriented DEA Models: An approach to major ports in India. Journal of Business and Economic Policy 1(2): 18-28.

Rao DS, Prasada, Timothy J.Coelli, MohammadA.2004. Agricultural productivity growth, employment and poverty in developing countries, 1970-2000. Employment Strategy Paper 2004/9.

Syahran R, Dedi BH, Dadang S.2016.The evaluation on the financial performance of paper and pulp companies in Indonesia. Indonesian Journal of Business and Entrepreneurship 2(3):187-196. https://doi.org/10.17358/IJBE.2.3.187.

Tambunan. 2001. Perekonomian Indonesia. Jakarta:Ghalia Indonesia.

Tanase, Ionela, Adriana T. 2012. Efficiency Progress and Productivity Change in Romania Machinery Industry 2001-2010. Procedia Economics and Finance 3 (2012): 1055-1062. https://doi. org/10.1016/S2212-5671(12)00273-0.

Vincent G. 1999. Ekonomi Manajerial Pembuatan Keputusan Bisnis. Jakarta: Gramedia Pustaka
Utama.

Yannick GZS, Zhao H, Belinga T. 2016. Technical efficiency assessment using data envelopment analysis: an application to the banking sector of Cote d'Ivoire. Procedia-Social and Behavioral Sciences 235(2016): 198-207. https://doi. org/10.1016/j.sbspro.2016.11.015.

Wu J, Qingxian A, Xin Y. 2014. Environmental efficiency evaluation of industry in China based on a new fixed sum undesirable output data envelopment analysis. Jounal of Cleaner Production 74(2014): 96-104. https://doi. org/10.1016/j.jclepro.2014.03.054.

Wu Y, Yong H, Xinli X, Chunyu M. 2016. Efficiency assessment of wind farms in China using two-stage data envelopment analysis. Energy Conversion and Management Journal 123(2016): 46-55. https://doi.org/10.1016/j. enconman.2016.06.014.

Zheng Q, Boqiang L. 2017. Industrial policies and improved energy efficiency in China's paper industry. Journal of Cleaner Production 161(2017): 200-210. https://doi.org/10.1016/j. jclepro.2017.05.025.

Zhu J. 2003. Quantitative Models for Performance Evaluation and Benchmarking, Data Envelopment Analysis with Spreadsheets and DEA Excel Solver. Massachusetts, USA: Worcester Polytechnic Institute. 